\title{
Chemically-Mediated Interactions Between Macroalgae, Their Fungal Endophytes, and Protistan Pathogens
}

\begin{abstract}
Marine Vallet ${ }^{1}$, Martina Strittmatter ${ }^{2}$, Pedro Murúa ${ }^{2}$, Sandrine Lacoste ${ }^{3}$, Joëlle Dupont ${ }^{3}$, Cedric Hubas ${ }^{4}$, Gregory Genta-Jouve ${ }^{1,5}$, Claire M. M. Gachon ${ }^{2}$, Gwang Hoon Kim ${ }^{6}$ and Soizic Prado ${ }^{1 *}$

${ }^{1}$ Muséum National d'Histoire Naturelle, Unité Molécules de Communication et Adaptation des Micro-organismes, UMR 7245, CP 54, Paris, France, ${ }^{2}$ The Scottish Association for Marine Science, Scottish Marine Institute, Oban, United Kingdom, ${ }^{3}$ Institut Systématique Evolution Biodiversité (ISYEB), Muséum National d'Histoire Naturelle, CNRS, Sorbonne Université, EPHE, Paris, France, ${ }^{4}$ Unité Biologie des organismes et écosystèmes aquatiques (UMR BOREA), Muséum national d'Histoire Naturelle, Sorbonne Université, Université de Caen Normandie, Université des Antilles, CNRS, IRD; Station Marine de Concarneau, Concarneau, France, ${ }^{5}$ Université Paris Descartes, Laboratoire de Chimie-Toxicologie Analytique et Cellulaire (C-TAC), UMR CNRS 8638, COMETE, Paris, France, ${ }^{6}$ Department of Biology, Kongju National University, Kongju, South Korea
\end{abstract}

Filamentous fungi asymptomatically colonize the inner tissues of macroalgae, yet their ecological roles remain largely underexplored. Here, we tested if metabolites produced by fungal endophytes might protect their host against a phylogenetically broad spectrum of protistan pathogens. Accordingly, the cultivable fungal endophytes of four brown algal species were isolated and identified based on LSU and SSU sequencing. The fungal metabolomes were tested for their ability to reduce the infection by protistan pathogens in the algal model Ectocarpus siliculosus. The most active metabolomes effective against the oomycetes Eurychasma dicksonii and Anisolpidium ectocarpii, and the phytomixid Maullinia ectocarpii were further characterized chemically. Several pyrenocines isolated from Phaeosphaeria sp. AN596H efficiently inhibited the infection by all abovementioned pathogens. Strikingly, these compounds also inhibited the infection of nori (Pyropia yezoensis) against its two most devastating oomycete pathogens, Olpidiopsis pyropiae, and Pythium porphyrae. We thus demonstrate that fungal endophytes associated with brown algae produce bioactive metabolites which might confer protection against pathogen infection. These results highlight the potential of metabolites to finely-tune the outcome of molecular interactions between algae, their endophytes, and protistan pathogens. This also provide proof-of-concept toward the applicability of such metabolites in marine aquaculture to control otherwise untreatable diseases.

Keywords: fungal endophytes, macroalgae, protistan pathogens, secondary metabolites, metabolome, molecular interactions, pyrenocines

\section{INTRODUCTION}

Macroalgae (seaweed) are important ecosystems engineers that contribute significantly to primary production in cold and temperate coastal seas and drive essential functions in nutrient cycling (Dayton, 1985). Macroalgae represent also a growing economic resource and their aquaculture has increased over the last decades, in particular for the Asian food market. In the last 25 years, 
the production of Pyropia (nori, formerly called Porphyra), the alga extensively used as sushi wrap in Asiatic cuisine, has more than tripled, mostly due to a rapid expansion in China and Korea. Accordingly, human consumption now represents $99 \%$ of the global algal market which keeps growing at an annual rate nearing 10\% (Food and Agricultural Organization of the United Nations (FAO), 2014).

Like most eukaryotes, macroalgae are colonized by widely diverse microorganisms that interact with them throughout their life cycle (Singh and Reddy, 2015). Bacterial communities associated with seaweed have profound effects on their growth, defense, development, and nutrition (Egan et al., 2013). Epiphytic bacterial communities are essential to the morphological development of certain green algae (Wichard et al., 2015) and numerous studies demonstrated the contribution of bacteria to nutrient acquisition or defense by the production of vitamins (Wichard and Beemelmanns, 2018). These multiple interactions led to define macroalgae and their associated microbiota as a "superorganism," called the holobiont (Egan et al., 2013).

Within this large microbial diversity, bacteria have been extensively studied, yet macroalgae also harbor a large diversity of fungi. The first report of an obligate mycophycobiosis between the Fucales Ascophyllum nodosum, Pelvetia canaliculata, and the fungal endosymbiont Stigmidium ascophylli (formerly Mycosphaerella ascophylli) dates back from more than a century (Cotton, 1907; Stanley, 1991), and it has been suggested that the symbiont may protect the algae host from desiccation, while obtaining nutrients in exchange (Garbary and Macdonald, 1995; Decker and Garbary, 2005). In the same vein, the fungal symbiont Turgidosculum ulvae colonizing the inner tissue of the green alga Blidingia minima can induce dark spots that are never consumed by the predatory gastropods of the host (Kohlmeyer and Volkmann-Kohlmeyer, 2003).

Many filamentous fungi can also asymptomatically colonize the algal inner tissues without causing any apparent damage or disease (Porras-Alfaro and Bayman, 2011; Debbab et al., 2012). These asymptomatic marine fungi remain mostly underexplored and only few reports can be found in the literature (Fries, 1979; Zuccaro et al., 2003, 2008; Harvey and Goff, 2010; Loque et al., 2010; Jones and Pang, 2012). However, thanks to recent DNA sequencing efforts, fungal diversity in marine substrata has been unraveled and now constitutes the second biggest known marine reservoir of fungi after sponges (Rateb and Ebel, 2011). This diversity encompasses mutualistic symbionts, opportunistic pathogens, parasites, and saprophytes (Zuccaro and Mitchell, 2005; Jones and Pang, 2012; Richards et al., 2012; Rédou et al., 2016). Recent studies related based on culture and molecular methods showed that ascomycetes are dominant endophytes of algae (Zuccaro et al., 2003, 2008; Flewelling et al., 2013a,b; Godinho et al., 2013).

In terrestrial plants, some well-known rhizosphere bacteria or root-colonizing fungi (i.e., Fusarium or Trichoderma) protect plants against phytopathogenic fungi or oomycetes (Haas and Defago, 2005; Terhonen et al., 2016). These mutualistic symbionts are often closely related to pathogens, and the beneficial nature of the interaction may depend on factors such as nutrition (Hiruma et al., 2016), age (Swett et al., 2017), or temperature (Tellenbach and Sieber, 2012). Similar examples are known in the phyllosphere; for example, cocoa trees inoculated with endophytes isolated from healthy leaves showed increased resistance to a Phytophthora pathogen (Arnold et al., 2003). The plant-endophyte coevolution hypothesis (Ji et al., 2009) suggests that endophytes might benefit plants by producing bioactive secondary metabolites. Indeed, endophytes isolated from Pezicula were shown to produce fungicidal metabolites toxic to the pathogens of their host (Arnold et al., 2003). Conversely, some endophytes may be latent or opportunistic pathogens when they exhibit virulence factors or produce toxic metabolites. Hence, the asymptomatic fungal colonization of plant organs would be the result of a balance between endophytic virulence and defense responses, preventing the development of disease (Schulz et al., 1999). In the phycosphere, endophytes are also able to produce bioactive antimicrobial metabolites (Zhang et al., 2009; Singh et al., 2015). It is thus plausible to assume that some secondary metabolites may mediate a mutualistic relationship, and may have a protective role toward other algaeassociated microbiotes such as pathogens.

Macroalgae, comparable with plants in this context, are indeed subject to numerous biotic stressors (Gachon et al., 2010; Thomas et al., 2014) such as viral, bacterial, fungal, oomycete, chytrid pathogens, and algal colonization in the form of endo- or epiphytes. In the seaweed industry, the oomycetes Olpidiopsis porphyrae and Pythium porphyrae are the most destructive pathogens of laver (Kim et al., 2014). As the industry quickly develops and intensifies, pathogen outbreaks are becoming a growing cause of concern. A recent Olpidiopsis outbreak in Korea was estimated to have reduced sale volumes by a quarter, notwithstanding the cost of disease management (Kim et al., 2014; Gachon et al., 2017). Crop protection measures are at best partially effective, and novel treatments are needed.

In brown algae, the obligate endobiotic oomycetes Eurychasma dicksonii and Anisolpidium ectocarpii are frequently found in the field (Sparrow, 1903) and able to infect more than 45 and 28 brown algal species in laboratory cultures, respectively (Gachon et al., 2010, 2017). They are amongst very few eukaryotic pathogens of algae that can be cultivated under laboratory conditions, including in the filamentous model brown seaweed Ectocarpus siliculosus.

The parasite Maullinia ectocarpii belongs to the Phytomyxea, a phylogenetically distant group of Rhizaria, can infect four different algae orders, including the Ectocarpales and Laminariales (Maier et al., 2000). This parasite is closely related to Maullinia braseltonii, an economically significant pathogen of bull kelp (Murúa et al., 2017). Therefore, these model pathogens constitute a powerful tool to investigate the responses of brown algae to infection, as their broad host range suggests that successful infection involves the overcoming core, conserved immune defenses. These pathogens can be cocultivated with their host and used as a pathosystem to perform functional bioassays. Compared to the economically-important kelp sporophytes, Ectocarpus is an excellent model organism, the microbiota of which can be easily manipulated (Müller et al., 2008; Tapia et al., 2016). As Ectocarpus is mostly composed of thin filaments, the commonly found endosymbionts are bacteria. 
The availability of its genome sequence as well as the possible powerful applications of genomics and genetics allow molecular and functional investigations (Peters et al., 2004).

Here, we hypothesized that secondary metabolites produced by endophytic fungi associated to brown algae may protect their host against several protistan pathogens of seaweeds, i.e., E. dicksonii, A. ectocarpii, and M. ectocarpii. We thus characterized the fungal endophytic strains isolated from A. nodosum, $P$. canaliculata, Laminaria digitata, and Saccharina latissima and demonstrated that some of them are able to protect the algal model E. siliculosus against pathogenic infection through the production of fungal metabolites belonging to the pyrenocine series (Figure S1). The pathosystem Eurychasma/Ectocarpus is one of the very few in vivo bioassay available to test the effect of substances against protistan pathogens of macroalgae. This broad-spectrum protection effect of the pyrenocines expanded to the most economically important oomycetes infecting the red seaweed Pyropia, Olpidiopsis pyropiae, and P. porphyrae. Notably, the pyrenocines are active against all tested pathogens but are also algicidal for the host E. siliculosus at higher concentration. These findings suggest for the first time that brown algae-derived endophytes may shape the infection outcome of algal pathogens by chemically protecting their host through the production of small chemicals cues.

\section{MATERIALS AND METHODS}

Laminariales L. digitata (LD) and S. latissima (SL) and two Fucales A. nodosum (AN) and Pelvetia caniculata (PC) according to the sampling data (Table S1). Three individuals of each species were collected during maxima low tide and processed within $2 \mathrm{~h}$ of collection. Algae organs of $5 \mathrm{~cm}^{2}$ (receptacles, thalli, stipes, fronds, and holdfasts) were excised and surface-sterilized by sequential immersion in Ethanol 70\% (30s), in $\mathrm{NaOCl} 0.1 \%$ $(30 \mathrm{~s})$, and washed three times (30s) in sterilized sea water (Kjer et al., 2010; Kientz et al., 2011). Algal segments were plated in multiples onto 4,200 plates representing 10 solid media ( $3 \%$ purified agar, $\mathrm{pH} 7.5,80 \%$ sterilized sea water) with the internal tissues in contact with the medium (about 200 segments per organ, 5,600 per individual, 16,800 per specieshost, 1,400 per medium type) and solidified with $20 \mathrm{~g} . \mathrm{L}^{-1}$ of purified agar (except for PDA). These media included Corn Flour Agar (Cornflour, La Vie Claire ${ }^{(}, 10$ g. $\mathrm{L}^{-1}$ ), Biomalt Agar 1 (Biomalt, Villa Natura ${ }^{\circledR}, 1$ g. $\mathrm{L}^{-1}$ ), Biomalt Agar 2 (Biomalt, Villa Natura ${ }^{\circledR}, 20$ g. $\mathrm{L}^{-1}$ ), Potato Dextrose Agar (Potato Dextrose Agar, Conda ${ }^{\circledR}, 20$ g. $\mathrm{L}^{-1}$ ), Yeast Extract Agar 1 (glucose 1 g.L $\mathrm{L}^{-1}$, soymeal peptone $0.5 \mathrm{~g} . \mathrm{L}^{-1}$, yeast extract $0.08 \mathrm{~g} . \mathrm{L}^{-1}$ ), Yeast Extract Agar 2 (glucose 0.1 g.L $\mathrm{L}^{-1}$, soymeal peptone 0.05 g.L $\mathrm{L}^{-1}$, yeast extract $0.01 \mathrm{~g} . \mathrm{L}^{-1}$ ), Malt Extract Agar (malt extract 20 g.L $\mathrm{L}^{-1}$, glucose $20 \mathrm{~g} . \mathrm{L}^{-1}$, peptone 1 g.L $\mathrm{L}^{-1}$ ), Tubaki Agar (glucose 30 g. $\mathrm{L}^{-1}$, yeast extract 1 g. $\mathrm{L}^{-1}$, peptone 1 g. $\mathrm{L}^{-1}$, $\mathrm{K}_{2} \mathrm{HPO}_{4} 1$ g.L $\mathrm{L}^{-1}, \mathrm{MgSO}_{4} 0.5$ g.L $\mathrm{L}^{-1}, \mathrm{FeSO}_{4} 0.01$ g.L $\mathrm{L}^{-1}$ ), Provasoli Agar $\left(\mathrm{Na}_{2} \beta\right.$-glycero $\mathrm{PO}_{4} .5 \mathrm{H}_{2} \mathrm{O} 50$ g.L $\mathrm{L}^{-1}, \mathrm{NaNO}_{3} 35$ g.L $\mathrm{L}^{-1}$, IronEDTA $\left(\mathrm{Fe}\left(\mathrm{NH}_{4}\right)_{2}\left(\mathrm{SO}_{4}\right)_{2} .6 \mathrm{H}_{2} \mathrm{O} 0.7\right.$ g.L ${ }^{-1}, \mathrm{Na}_{2}$ EDTA 0.6 g.L $\left.{ }^{-1}\right)$, Vitamin $B_{12} 0.01$ g.L $L^{-1}$, Thiamine 0.5 g. $\mathrm{L}^{-1}$, Biotin 0.005 g.L $\mathrm{L}^{-1}$, PII trace metals (Na $\mathrm{EDTA}_{1}$ g.L $\mathrm{L}^{-1}, \mathrm{H}_{3} \mathrm{BO}_{3} 1.12 \mathrm{g.L} \mathrm{L}^{-1}$,
$\mathrm{MnSO}_{4} \mathrm{H}_{2} \mathrm{O} 0.12$ g. $\mathrm{L}^{-1}, \mathrm{ZnSO}_{4} .7 \mathrm{H}_{2} \mathrm{O} 0.022$ g.L $\mathrm{L}^{-1}, \mathrm{CoSO}_{4} .7 \mathrm{H}_{2} \mathrm{O}$ 0.005 g.L $\left.{ }^{-1}\right)$, Stigmidium Fries Agar $\left(\mathrm{KNO}_{3} 0.72\right.$ g.L $\mathrm{L}^{-1}, \mathrm{~K}_{2} \mathrm{HPO}_{4}$ $1.2 \mathrm{~g} . \mathrm{L}^{-1}$, vitamin solution $1 \mathrm{~mL}$ (thiamin $100 \mathrm{mg} \cdot \mathrm{mL}^{-1}$, biotin $\left.25 \mathrm{mg} . \mathrm{mL}^{-1}\right), \mathrm{MgSO}_{4} .7 \mathrm{H}_{2} \mathrm{O} 0.7$ g.L $\mathrm{L}^{-1}, \mathrm{NaCl} 10 \mathrm{~g} . \mathrm{L}^{-1}$, glucose 20 g. $\mathrm{L}^{-1}$, traces element solution $1 \mathrm{~mL}\left(\mathrm{CaCl}_{2} 100 \mathrm{mg} \cdot \mathrm{mL}^{-1}\right.$, $\mathrm{ZnSO}_{4} .7 \mathrm{H}_{2} \mathrm{O} \quad 4.43 \mathrm{mg} \cdot \mathrm{mL}^{-1}, \quad \mathrm{MnSO}_{4} .4 \mathrm{H}_{2} \mathrm{O} \quad 4.03 \mathrm{mg} \cdot \mathrm{mL}^{-1}$, Ferric citrate $\mathrm{C}_{6} \mathrm{H}_{5} \mathrm{FeO}_{7} 4 \mathrm{mg} \cdot \mathrm{mL}^{-1}$ ). Plates were incubated at $18^{\circ} \mathrm{C}$ under ambient light and checked daily for endophytic growth up to 3 months. The percentages of infection per algal organ and per algal species were calculated by applying the following formulae: number of isolates recovered / total number of algal pieces deposited on agar medium.

\section{Sequencing and Molecular Identification of Algae-Associated Fungal Endophytes}

Fungal genomic DNA was extracted from fresh mycelium grown on different solid media. Extractions were performed using dneasy Plant Mini Kit (QIAGEN, Ltd. Crawley, UK) following the manufacturer's instructions. Different sets of primers were used to amplify different marker genes: LROR/LR6 primers (Vilgalys and Hester, 1990; Vilgalys and Lin Sun, 1994) were used to amplify a 600 base pair portion at the $5^{\prime}$ end of the nuclear ribosomal DNA large subunit, ITS4/ITS5 (White et al., 1990) were used to amplify the internal transcribed spacer region of the Ribosomal RNA operon, Bt2a/Bt2b (Glass and Donaldson, 1995) for a part of the 5 ' end of the beta tubulin coding gene when the ITS sequences were not informative enough to discriminate species of Aspergillus, Penicillium, and Talaromyces. PCR amplifications were performed according to previous studies (Lopez-Villavicencio et al., 2010; Langenfeld et al., 2013). PCR products were purified and sequenced using the dideoxy termination (Sanger) reaction by Eurofins MWG Operon ${ }^{\circledR}$ in Germany. Sequences were assembled with CodonCode Aligner v. 3.7.1. (Codon Code Corporation), checked by visual inspection of the chromatograms and edited if necessary. Molecular operational taxonomic units (MOTU) were defined using an arbitrary but commonly used threshold of 3\% intra-specific variability (Altschul et al., 1990; Nilsson et al., 2008; Tamura et al., 2013). MOTU were identified using the Blastn alignment tool (megablast algorithm optimized for highly similar sequences and excluding uncultured/environmental sample sequences) at http://blast.ncbi.nlm.nih.gov/Blast.cgi (Altschul et al., 1990). Best hits were carefully examined and sequences from taxonomic reference strains (AFTOL, CBS, DAOM, NRRL) were chosen preferably to attribute species names $(\geq 97 \%$ of sequence similarities). Sequences were aligned using the ClustalW tool available on MEGA version 6.0 software (Tamura et al., 2013). The phylogenetic tree was build using the same software, under a maximum likelihood framework. We used model test (Posada and Crandall, 2001) to choose the best nucleotide substitution model, namely GTR+I+G. Support for the branches was determined from bootstrap analysis of 1,000 resampled datasets (Figure 1). Sequences were deposited in GenBank under the accession numbers MH397587-MH397621 (28S) and MH397623-MH397663 (ITS) (Alignments S1-S3). 


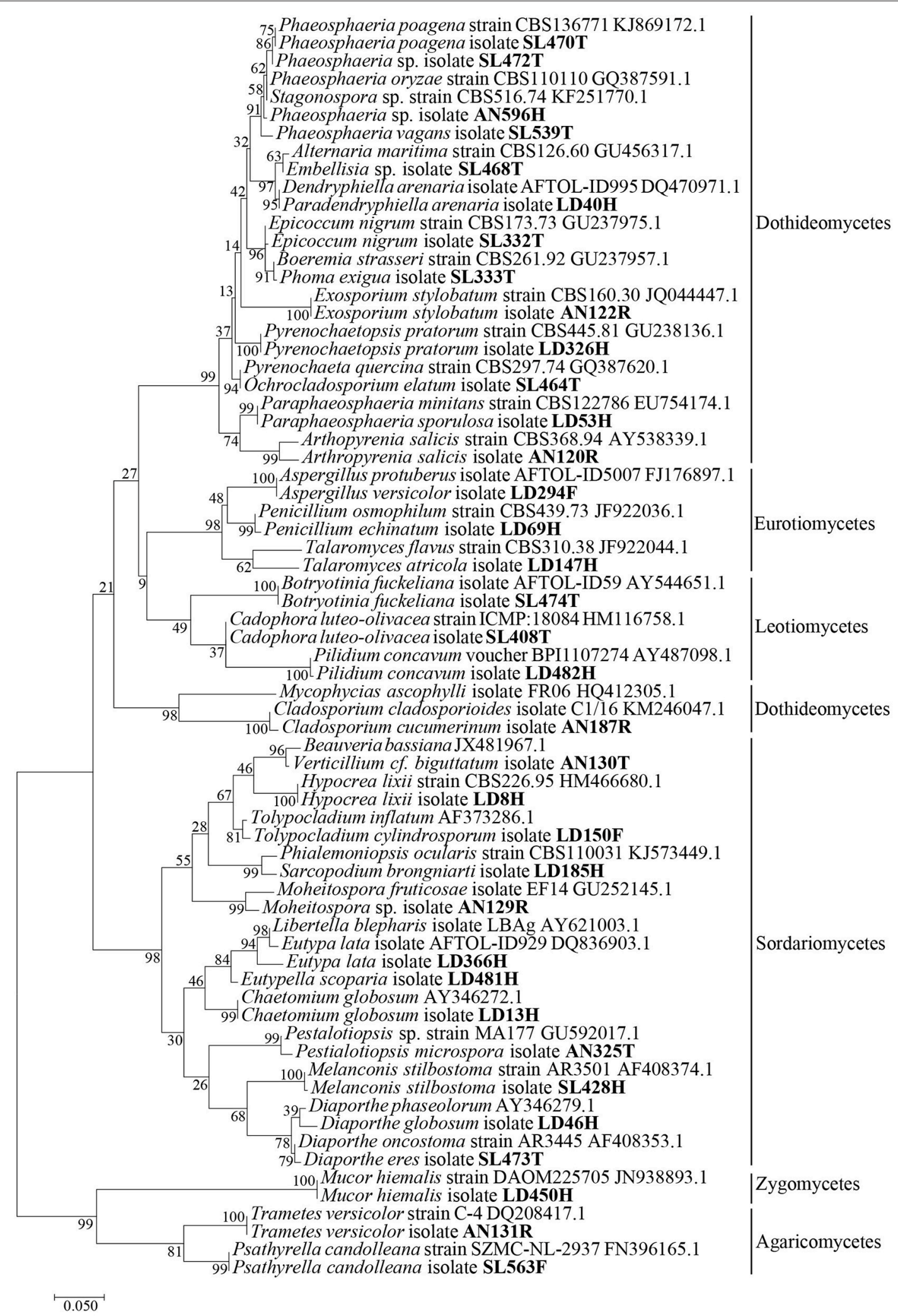

FIGURE 1 | Phylogenetic affinities based on LSU sequences of fungal endophytes isolates from the four brown algae sampled from French and Scottish sites. Isolate code are indicated in bold and accession numbers from reference sequences are marked in gray. Scale bar indicates $10 \%$ estimated sequence divergence. 


\section{Microorganisms, Fermentation, Extraction}

From the 99 isolates obtained, 70 were able to yield enough biomass for subsequent experiments. To build the extracts library, these strains were inoculated in a $12 \mathrm{~cm}^{2}$ Petri dish containing $60 \mathrm{~mL}$ (agar 1.5\%) of their respective isolation medium. The inoculation was made with spore suspension (100 $\mu \mathrm{L}, 10^{4}$ spores. $\left.\mathrm{mL}^{-1}\right)$ or from crushed mycelial suspension (1 $\mathrm{cm}^{2}$ in $2 \mathrm{~mL}$ of sterile ASW) for non-sporulating fungi. After incubation at $18^{\circ} \mathrm{C}$ for 27 days under a $12 \mathrm{~h}$ light: $12 \mathrm{~h}$ dark photoperiod, whole fungal culture (mycelium and $60 \mathrm{~mL}$ agar) were cut in $1 \mathrm{~cm}^{2}$ pieces and extracted by ethyl acetate $(3 \times$ $200 \mathrm{~mL}$ ) for $3 \times 1 \mathrm{~h}$ under sonication. The organic phases were filtrated, dried over anhydrous $\mathrm{MgSO}_{4}$ and concentrated under vacuum to yield crude extracts.

\section{Pyrenocines Isolation and Identification}

The fungi Phaeosphaeria sp. AN596H was grown in $5 \mathrm{~L}$ Erlenmeyer flasks $(5 \times 600 \mathrm{~mL}$ of TUA inoculated with $5 \mathrm{~mL}$ fungal suspension in sterile sterile deionized water) at $18^{\circ} \mathrm{C}$ for 27 days under a $12 \mathrm{~h}$ light: $12 \mathrm{~h}$ dark photoperiod. Extraction was performed with ethyl acetate (analytical grade, $3 \times 5 \mathrm{~L}$ ) under a mechanical agitation, organic phases were dried by anhydrous $\mathrm{MgSO}_{4}$, filtered, and concentrated under low vacuum to yield $2.3 \mathrm{~g}$ of a brown solid extract. The extract was solubilized in methanol and subjected to Sephadex ${ }^{\circledR}$ LH20 column chromatography (Sigma-Aldrich, Germany) with a $100 \%$ methanol elution. The active fraction $(82 \mathrm{mg}$ ) was further purified by preparative HPLC (Agilent PrepHT, column Eclipse XDB-C18 $21.2 \times 150 \mathrm{~mm}, 5 \mu \mathrm{m})$ under a flow rate of $10 \mathrm{~mL} \cdot \mathrm{min}^{-1}$ of analytical grade solvents buffer A: $95 \%$ water 5\% Acetonitrile, B: 95\% Acetonitrile 5\% water. This lead to the isolation of pyrenocines $A\left(R_{t}: 13 \mathrm{~min}, 7 \mathrm{mg}\right), B\left(R_{t}: 8 \mathrm{~min}\right.$, $5.5 \mathrm{mg}), \mathrm{E}\left(\mathrm{R}_{\mathrm{t}}: 14 \mathrm{~min}, 1 \mathrm{mg}\right)$, and pyrenochaetic acid $\mathrm{C}\left(\mathrm{R}_{\mathrm{t}}\right.$ : $23 \mathrm{~min}, 1.8 \mathrm{mg})$ along with the novel pyrenocine $\mathrm{S}\left(\mathrm{R}_{\mathrm{t}} 19 \mathrm{~min}\right.$, $2 \mathrm{mg}$ ). The infrared spectra were recorded on a Shimadzu FTIR8400 S spectrophotometer. Mass spectra were acquired on an API Q-STAR PULSAR mass spectrometer (Applied Biosystem, Bruker). NMR experiments were performed with Bruker advance III 400 and $600 \mathrm{MHz}$ spectrometers (Wissenbourg, France). Chemical shifts are expressed in $\delta(\mathrm{ppm})$ and were referred to the residual non-deuterated solvent signal.

\section{Disease Resistance Assays Using Algae-Pathogen Pathosystems}

Female gametophytes of Macrocystis pyrifera CCAP1323/1 infected with either E. dicksonii CCAP 4018/1 or CCAP 4018/3 were maintained in half-strength Provasoli medium at $15^{\circ} \mathrm{C}$ under daylight-type fluorescent lamps $\left(10 \mu \mathrm{mol} \cdot \mathrm{m}^{-2} \cdot \mathrm{s}^{-1}, 12 \mathrm{~h}\right.$ light: $12 \mathrm{~h}$ dark photoperiod). Batches of fast-growing cultures E. siliculosus CCAP 1310/4 were produced in $200 \mathrm{~mL}$ flasks. E. siliculosus was harvested in $70 \mu \mathrm{m}$ pore-size nylon mesh (Cell strainer, Falcon) and equivalent amounts were co-incubated in six-well polystyrene plates containing infected $M$. pyrifera CCAP $1323 / 1$ in $7 \mathrm{~mL}$ of half-strength Provasoli liquid medium for 16-20 days. The infections with A. ectocarpi CCAP 4001/1 and Maullinia ectocarpi CCAP1538/1 were performed with the same hosts during 3 and 10 days of co-incubation, respectively. The library of fungal extracts $\left(1 \mu \mathrm{g} \cdot \mathrm{mL}^{-1}\right.$ in dimethyl sulfoxide DMSO) was evaluated for their antipathogenic effect on the different pathogens. In all experiments, three controls were performed and consisted in incubating Ectocarpus alone (control uninfected), with parasites (control infected), and with addition of $1 \%$ DMSO (control infected + DMSO 1\%). The activity of purified compounds $\left(0.1 \mu \mathrm{g} . \mathrm{mL}^{-1}\right.$ in $1 \%$ DMSO) was assessed with the same procedure. After samples anonymization, filamentous E. siliculosus were delicately collected with extra thin needles (size 10-15, Hemline ${ }^{\circledR}$ ) and briskly transferred in 100 $\mu l$ of sterile seawater between slide and coverslip. Samples were maintained in a moist chamber and analyzed in the following hour. The infection of E. siliculosus filaments by protistan parasitoids was assessed under a microscope Axiovert2plus Zeiss (DIC, Plan Apochromat. $20 \times 0.75$ ) and pictures taken with camera Axocam HRc were analyzed with AxioVisio software (version 4.7). A scoring scale was defined by a (0) score if no infected cell was observed and $(1,2,3)$ scores, respectively, for $1-10,11-100$, or superior to 100 infected cells were observed. The Ectocarpus samples were then frozen at $-80^{\circ} \mathrm{C}$ in RNAlater stabilization reagent (QIAGEN). An identical protocol was used to evaluate the toxic activity of the pyrenocines on the algae $E$. siliculosus alone at $1 \mu \mathrm{g} \cdot \mathrm{mL}^{-1}$ in $1 \%$ DMSO.

\section{Evaluation Against Oomycete Pathogen Olpidiopsis Pyropia}

Gametophytic blades of Pyropia yezoensis infected with $O$. pyropiae were maintained in half-strength Provasoli medium at $15^{\circ} \mathrm{C}$ under daylight-type fluorescent lamps $\left(10 \mu \mathrm{mol} \cdot \mathrm{m}^{-2} \cdot \mathrm{s}^{-1}\right.$, $12 \mathrm{~h}$ photoperiod). The set up for the bioassay was exactly as those for evaluation against pathogens of E. siliculosus in six-well plates. The pyrenocines and pyrenochaetic acid $\mathrm{C}$ were added to the culture at the final concentration of $1 \mu \mathrm{g} \cdot \mathrm{ml}^{-1}$ (in DMSO $1 \%)$. Immediately after addition, infected area were observed for 10 min with an Olympus BX53 microscope (Olympus, Tokyo, Japan) and videos were recorded by a mounted Olympus DP72 camera.

\section{Pathogen Quantification With qPCR}

The relative abundance of the SSU rRNA for E. siliculosus and for $E$. dicksonii was quantified by qPCR using the validated primers pair (CG64/CG65) and (CG60/CG61), respectively (Amagata et al., 1998), as described in Gachon et al. (2009). PCR reactions were carried out in triplicate on a Quantica thermocycler (Techne-Barloworld) or a LightCycler ${ }^{\circledR}$ Roche (version 96SW1.1). The PCR mix for 1 sample contained $10 \mu \mathrm{L}$ 2x Mesagreen qPCR MasterMix Plus for SYBR ${ }^{\circledR}$ Assay, $1 \mu \mathrm{L}$ of each primer (final concentration $300 \mathrm{nM}$ ), $8 \mu \mathrm{L}$ DNA template for $20 \mu \mathrm{L}$ volume total. After a $10 \mathrm{~min}$ denaturation step at $95^{\circ} \mathrm{C}$, samples were run for 45 cycles of $15 \mathrm{~s}$ at $95^{\circ} \mathrm{C}$ and $1 \mathrm{~min}$ at $60^{\circ} \mathrm{C}$, followed by a dissociation curve. The disease scores were calculated by subtracting the threshold value obtained in the DNA amplification curve from the pathogen with that of the algae amplification curve. The disease scores were compared statistically by a one-way ANOVA with post-hoc Tukey HSD test. 


\section{RESULTS}

\section{Diversity and Phylogenetic Relationships of Filamentous Fungi Associated With Brown Macroalgae}

The diversity of endophytes was evaluated as previously described for endophytic isolation associated with macro-algae (Zuccaro et al., 2008), using a stringent disinfection protocol to avoid surface-associated microbial contamination. Concisely, 99 clonal isolates in total were purified from the 2,100 algae organs segments (Table 1), of which 30 were isolated from L. digitata (10 from Scotland and 20 from France), 17 from S. latissima in Oban, 49 strains from A. nodosum (5 from Scotland and 44 from France), and 3 from P. canaliculata. The frequency of colonies retrieved was low, with 99 positive segments over 2,100 incubated (4.7\%), and was irregular, ranging from 0 to $29 \%$ per algae organ and $1-14.6 \%$ per algae species (Table 1 ).

The receptacles were infected only in French $A$. nodosum ( $29 \%$ of the segments), while no fungi was isolated from the receptacles of Scottish Fucales. The most infected algae organs were the thalli (35 isolates) and holdfasts (32 isolates) but isolation success was irregular according to the algae species. Each algal segment yielded only one fungal strain at most. Among the 99 fungal isolates, 45 MOTU were identified, of which 35 were singletons (Table S2). An overview of phylogenetic relationships of the algicolous fungal isolates with referent fungal strains (Table S3) is summarized in a tree reconstructed based on LSU rDNA sequences alignment (Figure 1). Eurotiomycetes were further investigated by targeting the Tubuline marker (SI. Alignment 2) while all the fungal isolates identity was confirmed by sequencing the ITS region (SI. Alignment 3 ). The taxonomic assemblages and prevalence of the fungal classes recovered from the different host species and per algal organs were summarized in a mosaic-plot representation (Figure 2). Two MOTU were found to be predominant in this study, i.e., an unknown marine ascomycete related to Moheitospora sp. and the obligate marine fungus Paradendryphiella arenaria, representing, respectively, 37.4 and $8.1 \%$ of the isolates. The MOTU were phylogenetically diverse; most of them belong to Ascomycota (93.3\%) and very few to Basidiomycota (4.4\%) and Zygomycota (2.2\%). The fungal community of the Ascomycota was dominated by Dothideomycetes (37.8\%), with Pleosporales as the most abundant order, followed by Sordariomycetes (35.6\%), Eurotiomycetes (11.1\%), and Leotiomycetes (6.7\%) (Figure 2). In the sequence analysis, the taxonomic diversity was high but MOTU were mostly present as singletons (16 MOTU/17 isolates from S. latissima in Oban, 9 MOTU/10 isolates from $L$. digitata in Oban, 16 MOTU/20 isolates from L. digitata in Roscoff). The exception was in A. nodosum harvested in Roscoff where a lower diversity was observed with 8 MOTU identified among 44 isolates. However, most of the isolates ( 37 isolates: 14 in the thalli and 23 in the receptacles) belonged to same MOTU (Table S2). According to the sequence analysis, the fungi is related with 98$99 \%$ of identity to several Sordariomycetes marine fungi, Moheitospora fruticosae, Juncigena adarca, and M. chaetosa previously described by Kohlmeyer (Abdel-Wahab et al., 2010)

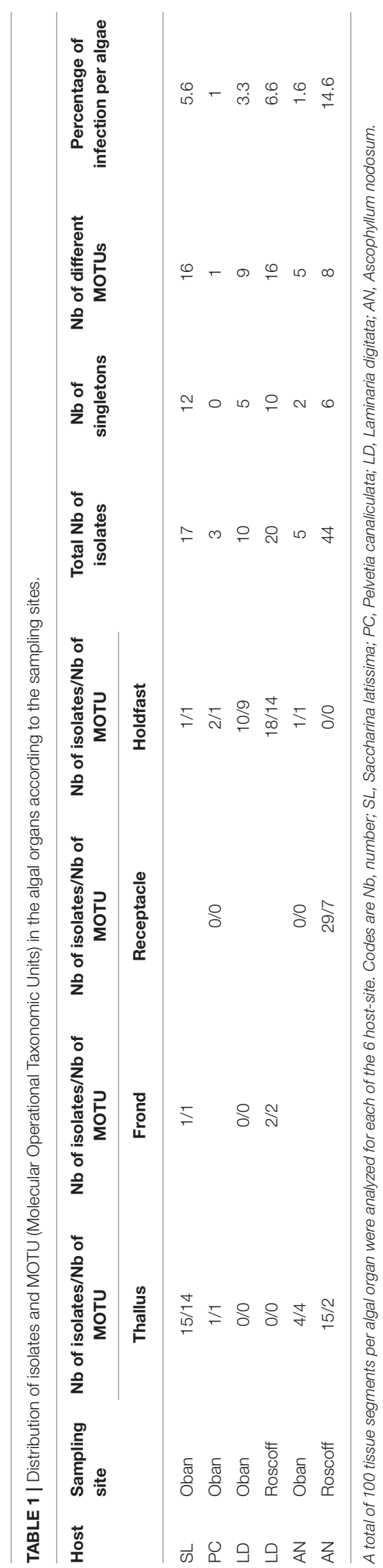


or Jones (Singh and Reddy, 2015). Only one MOTU, the obligate marine fungus $P$. arenaria, was present in all algae species.

\section{Screen of Fungal Metabolome Inhibiting Infection by Oomycete and Phytomixid Pathogens}

To assess the functional role of the isolated fungi against pathogens of seaweed, their extracts were tested against the pathosystem Ectocarpus/parasites. The brown seaweed E. siliculosus was thus infected by the oomycetes E. dicksonii, A. ectocarpii, or the phytomixid $M$. ectocarpii in presence of the fungal crude extracts. DMSO $1 \%$ was used as control and did not display any effect on the parasites' infection. This initial screening allowed the identification of five fungal extracts (Penicillium janczewskii LD68H, Phaeosphaeria sp. AN596H, Chaetomium globosum LD13H, C. globosum SL469 T, and Phoma exigua SL333T) which inhibit the infection by all the pathogens at 10 $\mu \mathrm{g} . \mathrm{mL}^{-1}$ with a broad-range spectrum (Figure 3). However, the $P$. arenaria $\mathrm{PC} 359 \mathrm{H}$ extract displayed a specific activity only against the two strains of E. dicksonii.

\section{Molecular Quantification of Eurychasma Dicksonii Infection}

In order to corroborate the microscopy results, the infection was also quantified by RT-qPCR for the experiments with $E$. dicksonii strains CCAP4018/1 and CCAP4018/3. The relative abundance of DNA from both host and pathogen was calculated (Gachon et al., 2009). A low disease score $(<20)$ corresponds to a high infection while a high score $(>20)$ indicate a lowlyinfected to uninfected algae. A linear regression analysis showed a positive correlation $\left(R^{2}=0.715\right)$ between the results obtained with the microscopy and qPCR evaluation methods (Figure S2). The results showed that the six most potent extracts unveiled by the microscopy assessment displayed high disease scores (Figure 4), confirmed further by one-way ANOVA with post-hoc Tukey HSD test $(F=10.97, p<0.001)$. Hence, the inhibition against tested algal pathogens by crude extracts obtained from Phaeosphaeria sp. AN596H, P. janczewskii LD68H, P. arenaria PC359H, C. globosum SL469T, C. globosum LD13H, and P. exigua SL333T were confirmed by two independent quantification methods.

\section{Secondary Metabolites Produced by Algicolous Fungi Phaeosphaeria sp. AN596H}

With respect to the potent antipathogenic activities, the identity of active compounds was investigated by a bioassay-guided fractionation method for the six fungal extracts. We succeed to recover enough quantity of the active fraction for further characterization only for the fungi Phaeosphaeria sp. AN596H. The fungal extract was subjected to successive chromatographic separation and yielded the pure compounds (1-5) (Figure S3). These compounds were structurally characterized by spectral comparison with the literature and belong to the pyrenocines family (Sato et al., 1979, 1981a,b; Amagata et al., 1998).
Pyrenocines A and B were the predominant compounds isolated, among the other minor pyrenocines $\mathrm{E}, \mathrm{C}$ and pyrenochaetic acid C. The assignment of the absolute configuration of pyrenocines $\mathrm{B}$ and $\mathrm{E}$ relied on the comparison of the theoretically calculated experimental values of optical rotations from the present study (Figure S3). In the course of this work, a new minor compound was also characterized and named pyrenocine $\mathrm{S}$ (Figure S3). This compound with the molecular formula $\mathrm{C}_{11} \mathrm{H}_{15} \mathrm{O}_{4}$ was deduced from the molecular peak at $m / z 211.0942[\mathrm{M}+\mathrm{H}]^{+}$(calc. 211.0970 ) and $\mathrm{m} / z 233.0792[\mathrm{M}+\mathrm{Na}]^{+}$(calc. 233.0790) in highresolution mass spectrometry. The ${ }^{1} \mathrm{H}$ NMR spectrum (Table S4, Figure S4) of $\mathbf{1}$ showed signals for three methyl groups, including a triplet at $\delta_{\mathrm{H}} 0.95(3 \mathrm{H}, \mathrm{J}=7.4 \mathrm{~Hz}, \mathrm{H}-10)$, a singlet at $\delta_{\mathrm{H}}$ $2.20(3 \mathrm{H}, \mathrm{H}-12)$, and a methoxy at $\delta_{\mathrm{H}} 3.91(3 \mathrm{H}, \mathrm{H}-11)$, two methylene at $\delta_{\mathrm{H}} 1.65(2 \mathrm{H}, \mathrm{J}=7.4 \mathrm{~Hz}, \mathrm{H}-9)$, and $2.73(2 \mathrm{H}$, $\mathrm{J}=7.2 \mathrm{~Hz}, \mathrm{H}-8)$ and an ethylenic proton resonating at $\delta_{\mathrm{H}}$ $5.64(1 \mathrm{H}, \mathrm{H}-3) .{ }^{13} \mathrm{C}$ NMR spectrum of 1 (Table S4, Figure S5) indicated the presence of five $\mathrm{sp}^{3}$ carbons: three methyls $\left(\delta_{\mathrm{C}}\right.$ $13.9,18.2$, and 57.4) and two methylenes $\left(\delta_{\mathrm{C}} 18.4\right.$ and 47.6). ${ }^{13} \mathrm{C}$ NMR spectrum of $\mathbf{1}$ also displayed one sp ${ }^{2}$ methine $\left(\delta_{\mathrm{C}}\right.$ $88.5, \mathrm{C}-3$ ) and five $\mathrm{sp}^{2}$ carbons (including two carbonyls at $\delta_{\mathrm{C}} 165.3$ and 202.6, two oxygenated at $\delta_{\mathrm{C}} 163.4$, and 170.7 and a quaternary at $\left.\delta_{\mathrm{C}} 117.4\right) .{ }^{1} \mathrm{H}-{ }^{1} \mathrm{H}$ COSY spectrum was indicative of a spin system between the both methylenes $\mathrm{H}-8$, $\mathrm{H}-9$ and the methyl $\mathrm{CH}_{3}-10$ (Figure 5). The HMBC correlations (Figure 5 and Figure S6) between the methine $\mathrm{H}-3$ and $\mathrm{C}-4\left(\delta_{\mathrm{C}}\right.$ $170.7) / \mathrm{C}-5\left(\delta_{\mathrm{C}} 117.4\right) / \mathrm{C}-2\left(\delta_{\mathrm{C}} 165.3\right)$ as well as the correlations between the methyl $\mathrm{CH}_{3}-12\left(\delta_{\mathrm{H}} 2.20\right)$ and $\mathrm{C}-6\left(\delta_{\mathrm{C}} 163.4\right) / \mathrm{C}$ 5 ( $\delta_{C}$ 117.4) suggested the presence of a methyl-pyran-2-one moiety in the structure. Moreover, HMBC correlation between methoxy $\left(\delta_{\mathrm{H}} 3.91\right)$ and $\mathrm{C}-4\left(\delta_{\mathrm{C}} 170.7\right)$ allowed to connect the methoxy group on C-4. Finally, HMBC correlations of methylenes $\mathrm{CH}_{2}-8$ and $\mathrm{CH}_{2}-9$ with the ketone $\mathrm{C}-7$ at $\delta_{\mathrm{C}} 202.6$ ppm as well as the HMBC correlations between $\mathrm{H}-3$ and C7 confirm the attachment of the aliphatic chain on C-5 of the cycle. All these data revealed the structure is a new pyrenocine for which the name pyrenocine $S$ was proposed. All identified compounds were thus further tested against the pathosystem Ectocarpus/parasites.

\section{Antiparasitic Activity of Pyrenocines and Pyrenochaetic Acid C}

To address the activity of the pyrenocines against protistan pathogens of brown algae, we screened compounds 1-4 for their potential inhibitory effect on the infection of E. siliculosus by E. dicksonii, A. ectocarpii, and M. ectocarpii (Figure 6). The pyrenocines $\mathrm{A}$ and $\mathrm{B}$ displayed a strong antipathogenic effect at $0.1 \mu \mathrm{g} . \mathrm{ml}^{-1}(0.4 \mu \mathrm{M})$ with a broad range spectrum in our assessment, while the other minor compounds did not have any effect except pyrenocines $E$ and $S$ active only against the strain $E$. dicksonii CCAP 418/3 (Figure 6). These results were confirmed by the qPCR evaluation for pyrenocine A (one-way ANOVA, $F$ $=11.91, p<0.001$ ). It is worth noting that in the course of our investigation, the pyrenocines were also tested at 10 -fold higher concentration $(4 \mu \mathrm{M})$ and induced the death of algal host cells (Figure S7). 


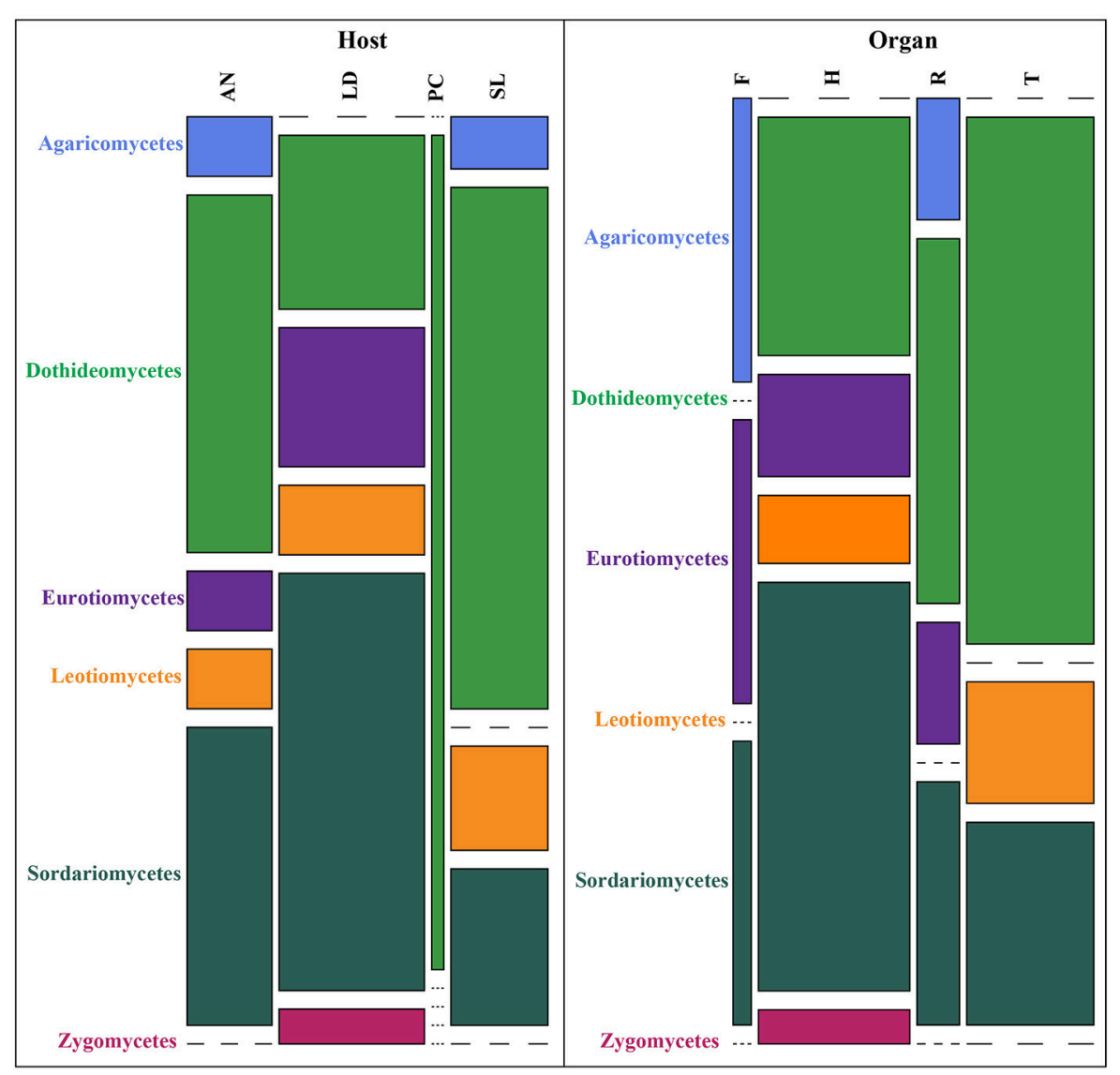

FIGURE 2 | Taxonomic assemblages of the fungal classes determined according to the different host-algae species and algal organs. Each class is displayed by a different color. Height of the bars represents the \% of each fungal class according to the host-algae species or the algal organs. Width of the bars represents the total number of OTUs according to the host-algae species or the algal organs. Codes for host species and algal organs are SL, Saccharina latissima; PC, Pelvetia canaliculata; LD, Laminaria digitata; AN, Ascophyllum nodosum; F, Frond; H, Holdfast; R, Receptacle; T, Thallus.

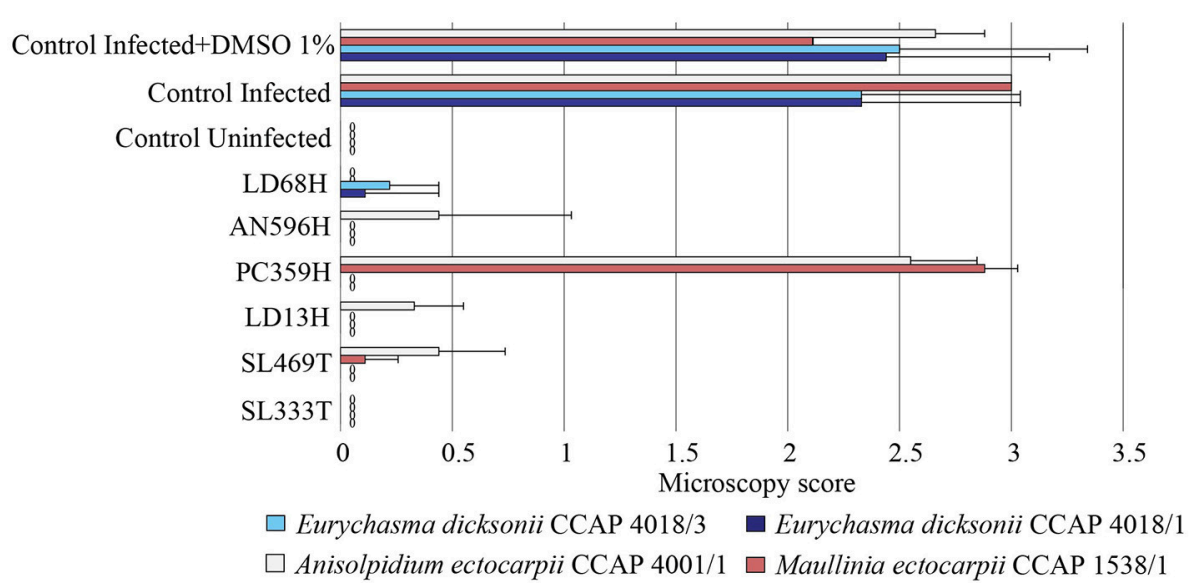

FIGURE 3 | Antipathogenic activities of the fungal extracts LD68H (Penicillium janczewskii), AN596H (Phaeosphaeria sp.), PC359H (Paradendryphiella arenaria), LD13H (Chaetomium globosum), SL469T (Chaetomium globosum), and SL333T (Phoma exigua) assessed on the infection of Ectocarpus siliculosus by Eurychasma dicksonii (CCAP 4018/1, CCAP 4018/3), Anisolpidium ectocarpii (CCAP 4001/1), and Maullinia ectocarpii (CCAP 1538/1). Controls consisted of algae alone (control uninfected), algae with parasite treatment (control infected), algae with parasite treatment, and 1\% DMSO (control infected + DMSO 1\%). Mean microscopy score values $\pm \mathrm{SE}$ are displayed for biological triplicates. 


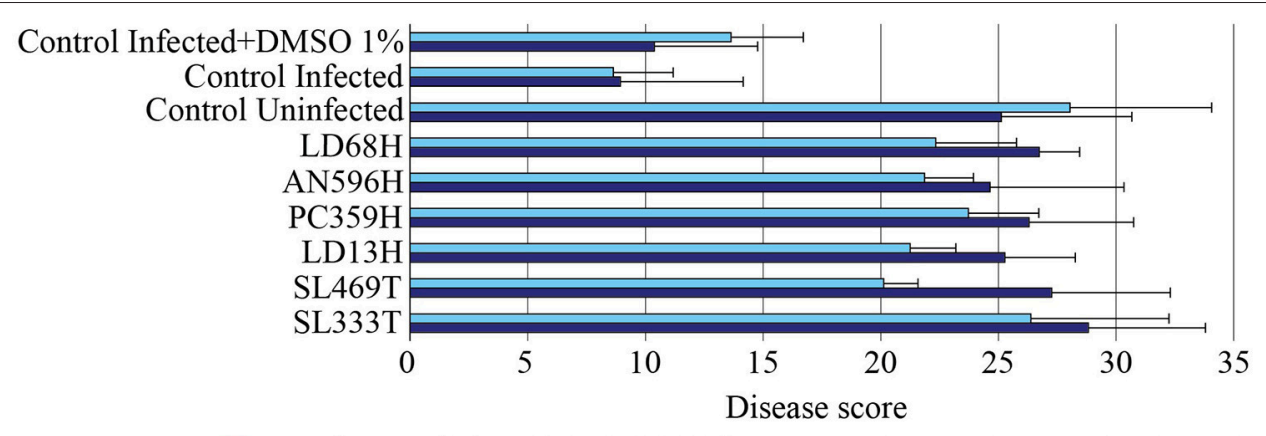

$\square$ Eurychasma dicksonii CCAP 4018/3 $\square$ Eurychasma dicksonii CCAP 4018/1

FIGURE 4 | Antipathogenic activities of the fungal extracts LD68H (Penicillium janczewskii), AN596H (Phaeosphaeria sp.), PC359H (Paradendryphiella arenaria), LD13H (Chaetomium globosum), SL469T (Chaetomium globosum), and SL333T (Phoma exigua) assessed by qPCR quantification of the infection of Ectocarpus siliculosus by Eurychasma dicksonii (CCAP 4018/1, CCAP 4018/3). Controls consisted of algae alone (control uninfected), algae with parasite treatment (control infected), algae with parasite treatment and 1\% DMSO (control infected + DMSO 1\%). Mean disease score \pm SE are displayed for biological triplicates.
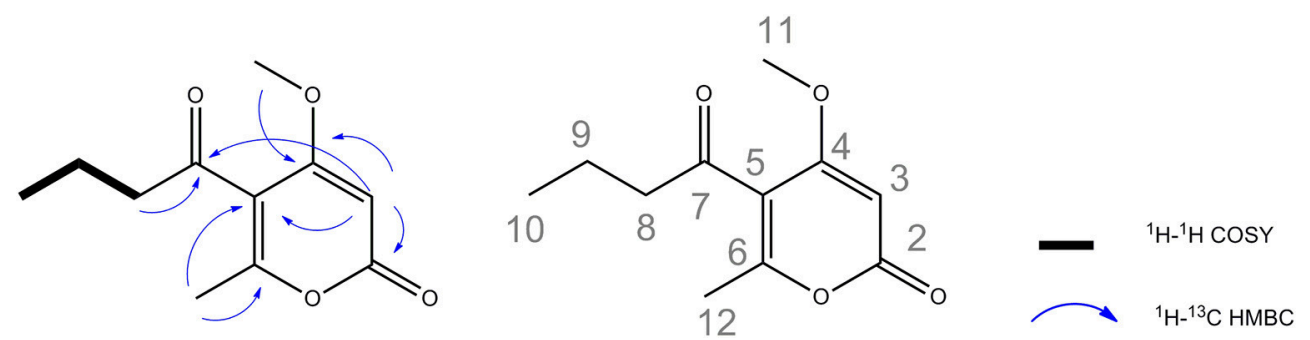

FIGURE 5 | Key HMBC and COSY correlations of the new pyrenocine S.

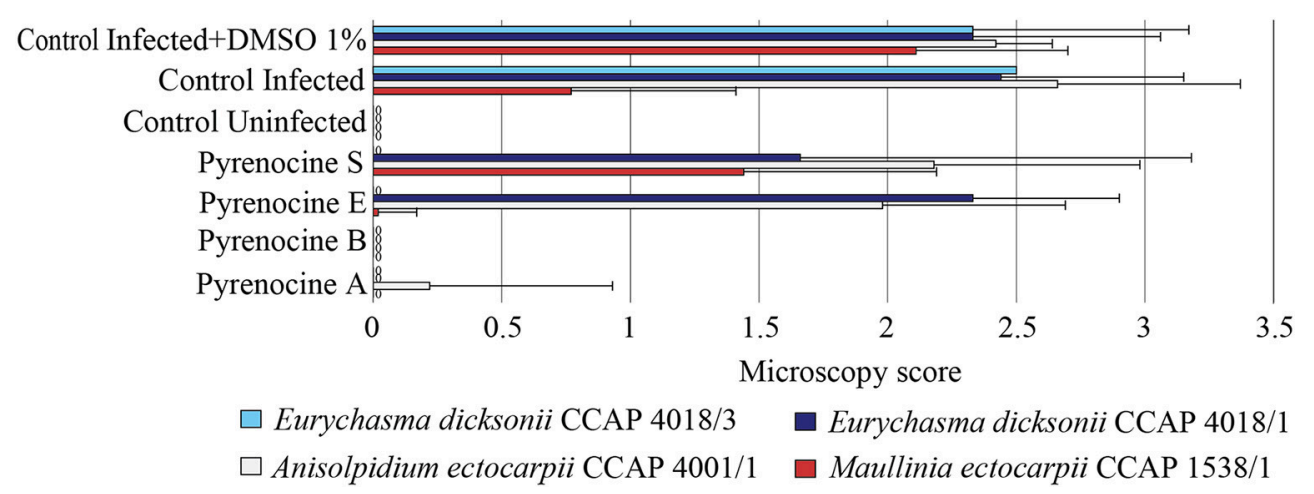

FIGURE 6 | Antipathogenic activities of the isolated assessed on the infection of Ectocarpus siliculosus by the pathogens Eurychasma dicksonii (CCAP4018/1, CCAP4018/3), Anisolpidium ectocarpii (CCAP 4001/1), and Maullinia ectocarpii (CCAP 1538/1). Controls consisted of algae alone (control uninfected), algae with parasite treatment (control infected), algae with parasite treatment and 1\% DMSO (control infected + DMSO 1\%). Mean microscopy score values \pm SE are displayed for biological triplicates.

\section{Protective Effect of Pyrenocines and Pyrenochaceatic Acid Against Oomycete Pathogens of Laver}

The pyrenocines and pyrenochaetic acid $\mathrm{C}$ were tested against the oomycetes $O$. pyropiae and $P$. porphyrae in the algae $P$. yezoensis. Pyrenocine A yielded a total inhibition of the infection of the host alga at $1 \mu \mathrm{g} \cdot \mathrm{ml}^{-1}(48 \mu \mathrm{M})$ while the pyrenochaetic acid C stopped the growth of $P$. porphyrae mycelium and induced its degeneration in 3 days. For instance, the collapse of zoosporangia of $O$. pyropia could be clearly observed with microscopy only few second after treatment with pyrenochaetic acid C (SI. Movie 1). Altogether, none of the added compounds induced any detectable changes in morphology, growth, and reproduction of the seaweed host $P$. yezoensis. These results 
clearly demonstrated the broad range effect of pyrenocines against protistan pathogens of seaweed.

\section{DISCUSSION}

This study highlighted a high phylogenetic diversity (45 MOTU) among the cultivable fungal endophytic community associated with the inner tissues of brown algae L. digitata, S. latissima, A. nodosum, and P. caniculata. The fungal species belonged to the Ascomycota, especially the Sordariomycetes and the Dothideomycetes (Figure 1). The proportion of taxa recovered within the main orders and classes were relatively similar to the ones described for marine fungi associated to plants or algae, in comparison with the public SSU rRNA reference sequences (Panzer et al., 2015). The prevalence of cultivable endophytes was very low (4.7\% overall) in comparison to the one commonly observed for terrestrial plants, as for example, fungi were successfully isolated from $99 \%$ of the Cephalotaxus harringtonia leaves tested (Langenfeld et al., 2013). The present findings are also consistent with the few existing surveys of cultivable endophytes associated with algae (Zuccaro et al., 2008; Flewelling et al., 2013a), but perhaps also due to our stringent surface disinfection protocol. However, only a few Penicillium and Aspergillus strains were isolated in this study in contrast to the fungal community associated with S. latissima harvested in the Atlantic Coast of Canada (Flewelling et al., 2013b).

Additionally, the taxonomic diversity and abundance of isolates differed between the algal organs tested, suggesting a potential tissue, and host preference. This pattern of fungal colonization may be explained by the differences in chemical composition and defense in algal species and organs (Megan et al., 2001; Cosse et al., 2009; Thomas et al., 2014). Notably, none of the fungi isolated from the brown algae A. nodosum was identified as Stigmidium ascophylli, despite its being a welldocumented Dothideomycetes mycophycobiont (Fries, 1979; Garbary and Gautam, 1989; Garbary et al., 1991; Stanley, 1991; Garbary and London, 1995; Garbary and Macdonald, 1995). However, a predominant fungus forming pink colonies similar to the cultivable one described by Fries (Fries, 1979) has been recovered from this algae and was identified as a Sordariomycete related to M. fruticosae, J. adarca, and Marinokulati chaetosa, that were previously described by Kohlmeyer (Abdel-Wahab et al., 2010) or Jones (Singh and Reddy, 2015). Our results also suggest that a second endophytic fungus may occur alongside Mycophycias ascophylli as a predominant colonizer of A. nodosum. A thorough year-long sampling across the coasts would certainly help in determining the natural prevalence of these fungal endophytes in the macroalgal community.

Aside from the cosmopolitan $P$. arenaria, which occurred in all four species investigated, few marine fungi sensu stricto or unknown species have been isolated (Michaelis et al., 1987; Cruz dela, 2006). Instead, most of the recovered strains are closely related to terrestrial phytopathogens (37\%), endophytes (21\%), or a miscellaneous group of lignivore, soil-borne, and airborne saprophytes (28\%) according to previous in the literature. Several genera, i.e., Acremonium, Coniothyrium, Botryotinia,
Phaeospharia, and Cordiceps have not been previously isolated from marine algal hosts (Flewelling et al., 2013a; Godinho et al., 2013,b). In particular, we retrieved sequences matching the phytopathogens $P$. exigua and Botryotinia fuckeliana. One hypothesis is therefore that these strains might be opportunistic pathogens, perhaps able to colonize an otherwise compromised alga. Nonetheless, known plant pathogens were found to live as endophytes in the liverwort Marchantia polymorpha and were able to confer growth benefits in a laboratory bioassay (Nelson et al., 2018). Hence, further research is required to ascertain the type of the interaction between these recovered fungi and brown algae, which could either be mutualist or pathogen. It should be borne in mind that these interactions may also depend upon the host genetic background, as shown recently for bacterial endosymbiont of insects (Cass et al., 2016).

Among the six fungal extracts that prevented or strongly inhibited infection by all three protistan pathogens of brown algae tested, the one obtained from Phaeosphaeria sp. AN596H lead to the successful chemical characterization of the active fraction. This fungal genus was found predominant in endophytes recovered from cold-adapted marine macrophytes (Zhang and Yao, 2015). Furthermore, a strain of Phaeosphaeria spartinae was isolated from the red alga Ceramium sp. and produced unusual polyketides and steroids (Elsebai et al., 2008; Elsebai et al., 2013). However, the ecological role of the fungus and its metabolites remain unknown.

Here, the fungal strain Phaeosphaeria sp AN596H was recovered from $A$. nodosum and five polyketides from the pyrenocine family were characterized. The pyrenocines A and B inhibit the infection of E. siliculosus by the protistan pathogens at the concentration of $0.1 \mu \mathrm{g} \cdot \mathrm{ml}^{-1}$. Pyrenocine A was first reported from the phytopathogen Pyrenochaeta terrestris (Sato et al., 1981a,b) and recently from the sponge-derived endophyte Penicillium paxilli (Toledo et al., 2014). The cytotoxic and antimicrobial properties of the pyrenocines has been reported in terrestrial ecosystems as, for example, pyrenocine A inhibits phytopathogens, and gram-positive bacteria at micromolar concentrations (Sparace et al., 1987; Rukachaisirikul et al., 2007; Toledo et al., 2014). This compound also displayed algicidal activity on E. siliculosus at $1 \mu \mathrm{g} \cdot \mathrm{ml}^{-1}$, but not on the red algae $P$. yezoensis at a similar concentration. Therefore, we hypothesize that at low concentration, fungal pyrenocines may confer protection to the alga against protistan pathogens, while being toxic at higher concentrations to some seaweed. However, the physiological concentrations at which pyrenocines were produced within the host $A$. nodosum are unknown and will have to be further investigated. The minor compounds pyrenocine $\mathrm{E}$, pyrenochaetic acid $C$, and the new natural product pyrenocine $S$ were also identified in the active extract, but did not displayed a broad range activity against the different protistan parasites. Pyrenocines $\mathrm{E}$ and $\mathrm{S}$ were found active against the strain $E$. dicksonii CCAP 418/3 giving evidence for strain-specific effect. Difference of activity for pyrenocines compounds could be also explained by their structural difference on the lateral chain suggesting structure-activity relationships.

Altogether, these results constitute the first example of a possible chemical mediation involved in a molecular interaction 
within the algal microbiota. We suggest that the endophytic continuum paradigm defined in planta might also possibly occur in brown algae (Schulz et al., 1999; Schulz and Boyle, 2005). Pathosystem bioassays with the alga model E. siliculosus were performed to identify fungal extracts and later the pyrenocines which are bioactive against phylogenetically unrelated pathogens. Importantly, these compounds also inhibit the infection of the most widely cultivated cultivar of laver in Korea by its two most important pathogens, the oomycetes $O$. pyropiae, and $P$. porphyrae.

\section{CONCLUSIONS}

These results provide for the first time evidence of fungal endophytes associated with brown macroalgae may protect their host in vivo through the production of small molecules. These data demonstrated that an active chemical defense produced by the algal microbiota may drive the infection success of pathogenic microbiotes in the phycosphere. Further studies using a broader range of algae species should be performed to evaluate the conservation of this chemical defense amidst hosts. Hence, these findings provide a proofof-concept to pursue the detailed chemical characterization of the other bioactive extracts identified, with the view to identify novel molecules with application in seaweed crop protection.

\section{AUTHOR CONTRIBUTIONS}

MV, PM, and MS carried out the experiments. MV, JD, and SL analyzed the data of molecular taxonomy. GG-J performed optical rotation calculations. MV, SP, and CG wrote the

\section{REFERENCES}

Abdel-Wahab, M. A., Pang, K. L., Nagahama, T., Abdel-Aziz, F. A., and Jones, E. B. G. (2010). Phylogenetic evaluation of anamorphic species of Cirrenalia and Cumulospora with the description of eight new genera and four new species. Mycol. Prog. 9, 537-558. doi: 10.1007/s11557-010-0661-x

Altschul, S. F., Gish, W., Miller, W., Myers, E. W., and Lipman, D. J. (1990). Basic local alignment search tool. J. Mol. Biol. 215, 403-410. doi: 10.1016/S0022-2836(05)80360-2

Amagata, T., Minoura, K., and Numata, A. (1998). Cytotoxic metabolites produced by a fungal strain from a Sargassum alga. J. Antibiot. 51, 432-434. doi: 10.7164/antibiotics.51.432

Arnold, A. E., Mejía, L. C., Kyllo, D., Rojas, E. I., Maynard, Z., Robbins, N., et al. (2003). Fungal endophytes limit pathogen damage in a tropical tree. Proc. Natl. Acad. Sci. U.S.A. 100, 15649-15654. doi: 10.1073/pnas.25334 83100

Cass, B. N., Himler, A. G., Bondy, E. C., Bergen, J. E., Fung, S. K., Kelly, S. E., et al. (2016). Conditional fitness benefits of the Rickettsia bacterial symbiont in an insect pest. Oecologia 180, 169-179. doi: 10.1007/s00442-0153436-x

Cosse, A., Potin, P., and Leblanc, C. (2009). Patterns of gene expression induced by oligoguluronates reveal conserved and environment-specific molecular defense responses in the Brown Alga Laminaria digitata. N. Phytol. 182, 239-250. doi: $10.1111 / j .1469-8137.2008 .02745 . x$

Cotton, A. D. (1907). Notes on marine pyrenomycetes. Trans. Br. Mycol. Soc. 3, 92-99. doi: 10.1016/S0007-1536(07)80023-4 manuscript with the help of $\mathrm{CH}, \mathrm{JD}$, and GHK. All authors conceived this study and approved the manuscript.

\section{FUNDING}

This work was supported by ATM Microorganisms grant from the Natural History Museum of Paris (SP), ASSEMBLE grant agreement No. 227799 (SP), and Initiative Structurante Ecosphère continentale et côtière EC2CO CNRS grant (SP). The $400 \mathrm{MHz}$ and $600 \mathrm{MHz}$ NMR spectrometers used in this study were funded jointly by the Région Ile-de-France, the MNHN (Paris, France), and the CNRS (France). This work was funded through the UK NERC IOF Pump-priming + scheme (NE/L013223/1, CMMG), the European Union's Horizon 2020 research and innovation (ALFF No 642575), the Genomia fund (award HERDIR, MS), the CONICYT (BecasChile $\mathrm{N}^{\circ}$ 72130422) (PM), and a MASTS Visiting Fellowship Scheme (SP).

\section{ACKNOWLEDGMENTS}

We acknowledge the Scottish Association for Marine Science (SAMS) and the Biological Station of Roscoff for hosting the field missions. We would like to greatly thank Philippe Potin (Marine Biology Station of Roscoff, France) for taxonomic identification of the brown macroalgae species during the field mission.

\section{SUPPLEMENTARY MATERIAL}

The Supplementary Material for this article can be found online at: https://www.frontiersin.org/articles/10.3389/fmicb. 2018.03161/full\#supplementary-material
Cruz dela, T. E. E. (2006). Marine Dendryphiella Species From Different Geographical Locations: An Integrated, Polyphasic Approach to Its Taxonomy and Physioecology. Dissertation, Technical Univeristy of Braunschweig.

Dayton, P. K. (1985). Ecology of kelp communities. Annu. Rev. Ecol. Syst. 16, 215-245. doi: 10.1146/annurev.es.16.110185.001243

Debbab, A., Aly, A., and Proksch, P. (2012). Endophytes and associated marine derived fungi-ecological and chemical perspectives. Fungal Divers 57, 45-83. doi: 10.1007/s13225-012-0191-8

Decker, R. J., and Garbary, D. J. (2005). Ascophyllum and its symbionts. VIII. Interactions among Ascophyllum nodosum (Phaeophyceae), Mycophycias ascophylli (Ascomycetes) and Elachista fucicola (Phaeophyceae). ALGAE 20, 363-368. doi: 10.4490/ALGAE.2005.20.4.363

Egan, S., Harder, T., Burke, C., Steinberg, P., Kjelleberg, S., and Thomas, T. (2013). The seaweed holobiont: understanding seaweed-bacteria interactions. FEMS Microbiol. Rev. 37, 462-476. doi: 10.1111/1574-6976. 12011

Elsebai, M. F., Eguereva, K., Almeida, C., Kehraus, S., and König, G. M. (2008). Isolation and structure elucidation of new polyketides from the marine-derived fungus Phaeosphaeria spartinae. Planta Med. 74:РB47. doi: $10.1055 / \mathrm{s}-0028-1084392$

Elsebai, M. F., Kehraus, S., and König, G. M. (2013). Caught between triterpene- and steroid-metabolism: $4 \alpha$-Carboxylic pregnane-derivative from the marine alga-derived fungus Phaeosphaeria spartinae. Steroids 78, 880-883. doi: 10.1016/j.steroids.2013.05.003

Flewelling, A. J., Ellsworth, K. T., Sanford, J., Forward, E., Johnson, J. A., and Gray, C. A. (2013a). Macroalgal endophytes from the Atlantic Coast of Canada: 
a potential source of antibiotic natural products? Microorganisms 1, 175-187. doi: 10.3390/microorganisms 1010175

Flewelling, A. J., Johnson, J. A., and Gray, C. A. (2013b). Isolation and bioassay screening of fungal endophytes from North Atlantic marine macroalgae. Bot. Mar. 56, 287-297. doi: 10.1515/bot-2012-0224

Food and Agricultural Organization of the United Nations (FAO) (2014). Fisheries and Aquaculture Information and Statistics Services. Available online at: http:// www.fao.org/figis/ (Accessed July 26, 2014).

Fries, N. (1979). Physiological characteristics of Mycosphaerella ascophylli, a fungal endophyte of the marine brown alga Ascophyllum nodosum. Physiol. Plant. 45, 117-121. doi: 10.1111/j.1399-3054.1979.tb01674.x

Gachon, C. M. M., Sime-Ngando, T., Strittmatter, M., Chambouvet, A., and Kim, G. H. (2010). Algal diseases: spotlight on a black box. Trends Plant Sci. 15, 633-640. doi: 10.1016/j.tplants.2010.08.005

Gachon, C. M. M., Strittmatter, M., Badis, Y., Fletcher, K. I., West, P. V., and Müller, D. G. (2017). Pathogens of brown algae: culture studies of Anisolpidium ectocarpii and $A$. rosenvingei reveal that the Anisolpidiales are uniflagellated oomycetes. Eur. J. Phycol. 52, 133-148. doi: 10.1080/09670262.2016.1252857

Gachon, C. M. M., Strittmatter, M., Müller, D. G., Kleinteich, J., and Küpper, F. C. (2009). Detection of differential host susceptibility to the marine oomycete pathogen Eurychasma dicksonii by real-Time PCR: not all algae are equal. Appl. Env. Microbiol. 75, 322-328. doi: 10.1128/AEM.01885-08

Garbary, D. J., Burke, J., and Lining, T. (1991). The Ascophyllum, Polysiphonia, Mycosphaerella Symbiosis. II. Aspects of the ecology and distribution of Polysiphonia lanosa in Nova Scotia. Bot. Mar. 34, 391-401. doi: 10.1515/botm.1991.34.5.391

Garbary, D. J., and Gautam, A. (1989). The Ascophyllum, Polysiphonia, Mycosphaerella symbiosis. I. population ecology of Mycosphaerella from Nova Scotia. Bot. Mar. 32, 181-186. doi: 10.1515/botm.1989.32.2.181

Garbary, D. J., and London, J. F. (1995). The Ascophyllum, Polysiphonia, Mycosphaerella symbiosis V. Fungal infection protects A. nosodum from desiccation. Bot. Mar. 38, 529-534. doi: 10.1515/botm.1995.38.1-6.529

Garbary, D. J., and Macdonald, K. A. (1995). The Ascophyllum Polysiphonia Mycosphaerella symbiosis 4. Mutualism in the Ascophyllum-Mycosphaerella interaction. Bot. Mar. 38, 221-225. doi: 10.1515/botm.1995.38.1-6.221

Glass, N. L., and Donaldson, G. C. (1995). Development of primer sets designed for use with the PCR to amplify conserved genes from filamentous ascomycetes. Appl. Env. Microbiol. 61, 1323-1330.

Godinho, V. M., Furbino, L. E., Santiago, I. F., Pellizzari, F. M., Yokoya, N. S., Pupo, D., et al. (2013). Diversity and bioprospecting of fungal communities associated with endemic and cold-adapted macroalgae in Antarctica. ISME J. 7, 1434-1451. doi: 10.1038/ismej.2013.77

Haas, D., and Defago, G. (2005). Biological control of soil-borne pathogens by fluorescent pseudomonads. Nat. Rev. Microbiol. 3, 307-319. doi: $10.1038 /$ nrmicro1129

Harvey, J. B. J., and Goff, L. J. (2010). Genetic covariation of the marine fungal symbiont Haloguignardia irritans (Ascomycota, Pezizomycotina) with its algal hosts Cystoseira and Halidrys (Phaeophyceae, Fucales) along the west coast of North America. Fungal Biol. 114, 82-95. doi: 10.1016/j.mycres.2009. 10.009

Hiruma, K., Gerlach, N., Sacristán, S., Nakano, R. T., Hacquard, S., Kracher, B., et al. (2016). Root endophyte colletotrichum tofieldiae confers plant fitness benefits that are phosphate status dependent. Cell 165, 464-474. doi: 10.1016/j.cell.2016.02.028

Ji, H. F., Li, X. J., and Zhang, H. Y. (2009). Natural products and drug discovery. Can thousands of years of ancient medical knowledge lead us to new and powerful drug combinations in the fight against cancer and dementia? EMBO Rep. 10, 194-200. doi: 10.1038/embor. 2009.12

Jones, E. B. G., and Pang, K. L. (2012). Marine fungi, and fungal-like organisms. De Gruyter GmbH. doi: 10.1515/9783110264067

Kientz, B., Thabard, M., Cragg, M. S., Pope, J., and Hellio, C. (2011). A new method for removing microflora from macroalgal surfaces: an important step for natural product discovery. Bot. Mar. 54, 457-469. doi: 10.1515/BOT. 2011.053

Kim, G. H., Moon, K. H., Kim, J. Y., Shim, J., and Klochkova, T. A. (2014). A revaluation of algal diseases in Korean Pyropia (Porphyra) sea farms and their economic impact. ALGAE 29, 249-265. doi: 10.4490/algae.2014.29.4.249
Kjer, J., Debbab, A., Aly, A. H., and Proksch, P. (2010). Methods for isolation of marine-derived endophytic fungi and their bioactive secondary products. Nat. Protoc. 5, 479-490. doi: 10.1038/nprot.2009.233

Kohlmeyer, J., and Volkmann-Kohlmeyer, B. (2003). Marine ascomycetes from algae and animal hosts. Bot. Mar. 46, 285-306. doi: 10.1515/BOT.2003.026

Langenfeld, A., Prado, S., Nay, B., Cruaud, C., Lacoste, S., Bury, E., et al. (2013). Geographic locality greatly influences fungal endophyte communities in Cephalotaxus harringtonia. Fungal Biol. 117, 124-136. doi: 10.1016/j.funbio.2012.12.005

Lopez-Villavicencio, M., Aguileta, G., Giraud, T., de Vienne, D. M., Lacoste, S., Couloux, A., et al. (2010). Sex in Penicillium: combined phylogenetic and experimental approaches. Fungal Genet. Biol. 47, 693-706. doi: 10.1016/j.fgb.2010.05.002

Loque, C. P., Medeiros, A. O., Pellizzari, F. M., Oliveira, E. C., Rosa, C. A., and Rosa, L. H. (2010). Fungal community associated with marine macroalgae from Antarctica. Polar Biol. 33, 641-648. doi: 10.1007/s00300-009-0740-0

Maier, I., Parodi, E., Westermeier, R., and Müller, D. G. (2000). Maullinia ectocarpii gen. et sp. nov. (Plasmodiophorea), an intracellular parasite in Ectocarpus siliculosus (Ectocarpales, Phaeophyceae) and other filamentous brown algae. Protist 151, 225-238. doi: 10.1078/1434-4610-00021

Megan, N. D., Kathryn, L. V. A., and David, O. D. (2001). "Spatial patterns in macroalgal chemical defenses," in Marine Chemical Ecology (Boca Raton, FL: CRC Press), 301-324.

Michaelis, K. C., Gessner, R. V., and Romano, M. A. (1987). Population genetics and systematics of marine species of Dendryphiella. Mycologia 79, 514-518. doi: 10.1080/00275514.1987.12025418

Müller, D. G., Gachon, C., and Küpper, F. (2008). Axenic clonal cultures of filamentous brown algae: initiation and maintenance. Cahiers Biol. Mar. 49, 59-65.

Murúa, P., Goecke, F., Westermeier, R., van West, P., Küpper, F. C., and Neuhauser, S. (2017). Maullinia braseltonii sp. nov. (Rhizaria, Phytomyxea, Phagomyxida): A Cyst-forming parasite of the bull kelp Durvillaea spp. (Stramenopila, Phaeophyceae, Fucales). Protist 168, 468-480. doi: 10.1016/j.protis.2017. 07.001

Nelson, J. M., Hauser, D. A., Hinson, R., and Shaw, A. J. (2018). A novel experimental system using the liverwort Marchantia polymorpha and its fungal endophytes reveals diverse and context-dependent effects. N. Phytol. 218, 1217-1232. doi: 10.1111/nph.15012

Nilsson, R. H., Kristiansson, E., Ryberg, M., Hallenberg, N., and Larsson, K. H. (2008). Intraspecific ITS variability in the Kingdom fungi as expressed in the international sequence databases and its implications for molecular species identification. Evol. Bioinform. 4, 193-201. doi: 10.4137/EBO.S653

Panzer, K., Yilmaz, P., Weiss, M., Reich, L., Richter, M., Wiese, J., et al. (2015). Identification of habitat-specific biomes of aquatic fungal communities using a comprehensive nearly full-length $18 \mathrm{~S}$ rRNA dataset enriched with contextual data. PLoS ONE 10:e134377. doi: 10.1371/journal.pone.0134377

Peters, A. F., Marie, D., Scornet, D., Kloareg, B., and Cock, M. J. (2004). Proposal of Ectocarpus siliculosus (Ectocarpales, Phaeophyceae) as a model organism for brown algal genetics and genomics. J. Phycol. 40, 1079-1088. doi: 10.1111/j.1529-8817.2004.04058.x

Porras-Alfaro, A., and Bayman, P. (2011). Hidden fungi, emergent properties: endophytes and microbiomes. Ann. Rev. Phytopath. 49, 291-315. doi: 10.1146/annurev-phyto-080508-081831

Posada, D., and Crandall, K. A. (2001). Intraspecific gene genealogies: trees grafting into networks. Trends Ecol. Evol. 16, 37-45. doi: 10.1016/S0169-5347(00)02026-7

Rateb, M. E., and Ebel, R. (2011). Secondary metabolites of fungi from marine habitats. Nat. Prod. Rep. 28, 290-344. doi: 10.1039/c0np00061b

Rédou, V., Vallet, M., Meslet-Cladière, L., Kumar, A., Pang, K. L., Pouchus, Y. F., et al. (2016). "Marine Fungi," in The Marine Microbiome: An Untapped Source of Biodiversity and Biotechnological Potential, eds L. J. Stal and M. S. Cretoiu (Cham: Springer International Publishing), 99-153. doi: 10.1007/978-3-319-33000-6_4

Richards, T. A., Jones, M. D. M., Leonard, G., and Bass, D. (2012). Marine fungi: their ecology and molecular diversity. Annu. Rev. Mar. Sci. 4, 495-522. doi: 10.1146/annurev-marine-120710-100802

Rukachaisirikul, V., Kaeobamrung, J., Panwiriyarat, W., Saitai, P., Sukpondma, Y., Phongpaichit, S., et al. (2007). A new pyrone derivative from the endophytic 
fungus Penicillium paxilli PSU-A71. Chem. Pharm. Bull. 55, 1383-1384. doi: $10.1248 / \mathrm{cpb} .55 .1383$

Sato, H., Konoma, K., and Sakamura, S. (1979). Phytotoxins produced by onion pink root fungus, Pyrenochaeta terrestris. Agric. Biol. Chem. 43, 2409-2411.

Sato, H., Konoma, K., and Sakamura, S. (1981a). Three new phytotoxins produced by Pyrenochaeta terrestris: pyrenochaetic acids A, B and C. Agric. Biol. Chem. 45, 1675-1679. doi: 10.1271/bbb1961.45.1675

Sato, H., Konoma, K., Sakamura, S., Furusaki, A., Matsumoto, T., and Matsuzaki, T. (1981b). X-ray crystal structure of pyrenocine A, a phytotoxin from Pyrenochaeta terrestris. Agric. Biol. Chem. 45, 795-797. doi: $10.1271 /$ bbb1961.45.795

Schulz, B., and Boyle, C. (2005). The endophytic continuum. Mycol. Res. 109, 661-686. doi: 10.1017/S095375620500273X

Schulz, B., Römmert, A. K., Dammann, U., Aust, H. J., and Strack, D. (1999). The endophyte-host interaction: a balanced antagonism? Mycol. Res. 103, 1275-1283. doi: $10.1017 / \mathrm{S} 0953756299008540$

Singh, R. P., Kumari, P., and Reddy, C. R. K. (2015). Antimicrobial compounds from seaweeds-associated bacteria and fungi. Appl. Microbiol. Biotech. 99, 1571-1586. doi: 10.1007/s00253-014-6334-y

Singh, R. P., and Reddy, C. R. (2015). Unraveling the functions of the macroalgal microbiome. Front. Microbiol. 6:1488. doi: 10.3389/fmicb.2015.01488

Sparace, S. A., Reeleder, R. D., and Khanizadeh, S. (1987). Antibiotic activity of the pyrenocines. Can. J. Microbiol. 33, 327-330. doi: 10.1139/m87-055

Sparrow, F. K. (1903). Aquatic Phycomycetes. Ann Arbor, MI: University of Michigan Press.

Stanley, S. J. (1991). The Autecology and Ultrastructural Interactions Between Mycosphaerella Ascophylli Cotton, Lautitia Danica (Berlese) Schatz, Mycaureola Dilseae Maire Et. Chemin: And Their Respective Marine Algal Hosts. Portsmouth Polytechnic.

Swett, C. L., Gordon, T. R., and Woodward, S. (2017). Exposure to a pine pathogen enhances growth and disease resistance in Pinus radiata seedlings. For. Pathol. 47:e12298. doi: 10.1111/efp.12298

Tamura, K., Stecher, G., Peterson, D., Filipski, A., and Kumar, S. (2013). MEGA6: molecular evolutionary genetics analysis version 6.0. Mol. Biol. Evol. 30, 2725-2729. doi: 10.1093/molbev/mst197

Tapia, J. E., Gonzalez, B., Goulitquer, S., Potin, P., and Correa, J. A. (2016). Microbiota influences morphology and reproduction of the brown alga Ectocarpus sp. Front. Microbiol. 7:197. doi: 10.3389/fmicb.2016. 00197

Tellenbach, C., and Sieber, T. N. (2012). Do colonization by dark septate endophytes and elevated temperature affect pathogenicity of oomycetes? FEMS Microbiol. Ecol. 82, 157-168. doi: 10.1111/j.1574-6941.2012.01415.x

Terhonen, E., Sipari, N., and Asiegbu, F. O. (2016). Inhibition of phytopathogens by fungal root endophytes of Norway spruce. Biol. Control 99, 53-63. doi: 10.1016/j.biocontrol.2016.04.006

Thomas, F., Cosse, A., Le Panse, S., Kloareg, B., Potin, P., and Leblanc, C. (2014). Kelps feature systemic defense responses: insights into the evolution of innate immunity in multicellular eukaryotes. N. Phytol. 204, 567-576. doi: $10.1111 /$ nph. 12925

Toledo, T. R., Dejani, N. N., Monnazzi, L. G. S., Kossuga, M. H., Berlinck, R. G. S., Sette, L. D., et al. (2014). Potent anti-inflammatory activity of pyrenocine A isolated from the marine-derived fungus Penicillium paxilli $\mathrm{Ma}(\mathrm{G}) \mathrm{K}$. Mediat. Inflamm. 2014:767061. doi: 10.1155/2014/767061

Vilgalys, R., and Hester, M. (1990). Rapid genetic identification and mapping of enzymatically amplified ribosomal DNA from several Cryptococcus species. J. Bacteriol. 172, 4238-4246. doi: 10.1128/jb.172.8.4238-4246.1990

Vilgalys, R., and Lin Sun, B. (1994). Ancient and recent patterns of geographic speciation in the oyster mushrum Pleurotus revealed by phylogenetic analysis of ribosomal DNA sequences. Proc. Natl. Acad. Sci. U.S.A. 91, 4599-4603. doi: 10.1073/pnas.91.10.4599

White, T., Bruns, T., Lee, S., and Taylor, J. (1990). "Amplification and direct sequencing of fungal ribosomal RNA genes for phylogenetics," in PCR Protocols: A Guide to Methods and Applications, eds M. Innis, D. Gelfand, J. Shinsky, and T. White (Academic Press), 315-322.

Wichard, T., and Beemelmanns, C. (2018). Role of chemical mediators in aquatic interactions across the Prokaryote-Eukaryote boundary. J. Chem. Ecol. 44:1008-1021. doi: 10.1007/s10886-018-1004-7

Wichard, T., Charrier, B., Mineur, F., Bothwell, J. H., Clerck, O. D., and Coates, J. C. (2015). The green seaweed Ulva: a model system to study morphogenesis. Front. Plant Sci. 6:72. doi: 10.3389/fpls.2015. 00072

Zhang, T., and Yao, Y. F. (2015). Endophytic fungal communities associated with vascular plants in the High Arctic Zone are highly diverse and host-plant specific. PLOS ONE 10:e0130051. doi: 10.1371/journal.pone. 0130051

Zhang, Y., Mu, J., Feng, Y., Kang, Y., Zhang, J., Gu, P. J., et al. (2009). Broad-spectrum antimicrobial epiphytic and endophytic fungi from marine organisms: isolation, bioassay and taxonomy. Mar. Drugs 7, 97-112. doi: $10.3390 / \mathrm{md} 7020097$

Zuccaro, A., and Mitchell, J. L. (2005). "Fungal communities of seaweeds," in The Fungal Community, 3rd Edn, eds J. F. W. J. Dighton Jr., and P. Oudemans (New York, NY:VCRC Press) 533-579. doi: 10.1201/9781420027891. $\operatorname{ch} 27$

Zuccaro, A., Schoch, C. L., Spatafora, J. W., Kohlmeyer, J., Draeger, S., and Mitchell, J. I. (2008). Detection and identification of fungi intimately associated with the brown seaweed Fucus serratus. App. Env. Microbiol. 74, 931-941. doi: 10.1128/AEM.01158-07

Zuccaro, A., Schulz, B., and Mitchell, J. I. (2003). Molecular detection of ascomycetes associated with Fucus serratus. Mycol. Res. 107, 1451-1466. doi: $10.1017 /$ S0953756203008657

Conflict of Interest Statement: The authors declare that the research was conducted in the absence of any commercial or financial relationships that could be construed as a potential conflict of interest.

Copyright $(\odot) 2018$ Vallet, Strittmatter, Murúa, Lacoste, Dupont, Hubas, Genta-Jouve, Gachon, Kim and Prado. This is an open-access article distributed under the terms of the Creative Commons Attribution License (CC BY). The use, distribution or reproduction in other forums is permitted, provided the original author(s) and the copyright owner(s) are credited and that the original publication in this journal is cited, in accordance with accepted academic practice. No use, distribution or reproduction is permitted which does not comply with these terms. 